\title{
A korai iskolaelhagyás csökkentését célzó szakpolitika - ismertető
}

\author{
Policy of reducing early school leaving - review
}

\author{
Szerző: Solymosy József Bonifácz $\bowtie$ \\ Nemzeti Egészségfejlesztési Intézet
}

Beküldve: 2016.11.11.

Kulcsszavak: korai iskolaelhagyás, stratégiai szakpolitika, szektorokon átívelő stratégiák, EU 2020 stratégia

Keywords: early school leaving, strategic policy, cross sectoral strategies, Europe 2020 strategy

A Kormány 1603/2014. (XI. 4.) Korm. határozata, a Magyar nemzeti társadalmi felzárkózási stratégia II., Az egész életen át tartó tanulás szakpolitikájának keretstratégiája, a Köznevelés-fejlesztési stratégia, továbbá a Végzettség nélküli iskolaelhagyás elleni középtávú stratégia elfogadásáról döntött. ${ }^{1}$ Ezen dokumentumok közül most, a „Végzettség nélküli iskolaelhagyás elleni középtávú stratégia" szakanyagra szeretnénk felhívni az olvasók figyelmét. ${ }^{2}$

\section{NÉHÁNY MEGÁLLAPÍTÁS A VEZETŐI ÖSSZEFOG- LALÓBÓL}

„Az Európai Unió stratégiai célja a foglalkoztatottak arányának 75\%-ra történő növelése, és ezzel egyidejűleg a foglalkoztathatóság javítása 2020-ig. A foglalkoztathatóság szoros összefüggést mutat az iskolai végzettség szintjével, a képesítésekkel, ezért is irányul az Európa 2020 stratégia öt számszerü célkitűzéseinek egyike az alacsony iskolai végzettségűek arányának visszaszorítására. A célkitúzés sze- rint, az EU átlagában az oktatást-képzést középfokú végzettség/szakképzettség nélkül elhagyó 18-24 évesek arányát, a korosztály 10 százaléka alá kell csökkenteni." ${ }^{\prime \prime}$

„Az Európai Unió Oktatási Tanácsa 2011-ben Ajánlást fogadott el a korai iskolaelhagyás csökkentését célzó szakpolitikákról. ${ }^{3} \mathrm{~A}$ tanácsi Ajánlás felhívja a tagállamok figyelmét arra, hogy azonosítsák a végzettség nélküli iskolaelhagyást előidéző társadalmi és oktatási tényezőket, folyamatosan figyeljék a leginkább veszélyeztetett célcsoportok tanulási pályáját, építsenek ki korai jelzőrendszert a végzettség nélküli iskolaelhagyás megelőzése céljából, és dolgozzanak ki specifikus beavatkozásokat azok számára, akik ezek nélkül biztosan kihullanának az oktatási rendszerből. Végül legyenek olyan kompenzáló, második esély programjaik, amelyek a nappali tagozatos, iskola-rendszerú oktatásból már kimaradtak számára biztosítják a foglalkoztathatósághoz szükséges készségek, képességek elsajátításának esélyét."

\footnotetext{
'A korai iskolaelhagyás rátája az Európai Unióban hivatalosan használt definíció szerint azon 18-24 évesek arányát méri, akiknek (még) nincsen középfokú (ISCED 3 szintű, szakmunkás vagy érettségi típusú) végzettsége, és nem is vesznek részt oktatásban vagy képzésben. A mutatót az Eurostat által koordinált éves, nagymintás munkaerő-felvétel alapján számítják. A mutató tulajdonképpen egy alsó becslés, hiszen a 18-24 éves, oktatásban résztvevők egy bizonyos hányada később sem fog középfokú végzettséget szerezni. Ráadásul a felmérés bármilyen, tehát nem végzettséghez vezető oktatásban való részvétel esetén sem sorol egy fiatalt a korai iskolaelhagyók közé.
} 
„A végzettség nélküli iskolaelhagyás az iskolai kudarcok, a lemorzsolódás gyakori következményére, az alacsony iskolázottságra, továbbá ennek eredményeképpen a munkaerôpiacról és a társadalomból való kirekesztődés veszélyére irányítja a figyelmet. A fogalom mögött álló társadalompolitikai megközelítésből következően, a végzettség nélküli iskolaelhagyás elleni stratégia beavatkozásainak nemcsak a 18-24 év közötti fiatalokra, hanem - a probléma újratermelődésének megfékezése érdekében - a korábbi iskolaköteles, valamint az iskoláskor előtti korosztályokra is ki kell terjednie.

A magyar Kormány az EU 2020 stratégia céljainak hazai megvalósítását szolgáló Nemzeti Reform Programjában vállalta, hogy a végzettség nélküli iskolaelhagyók arányát az évtized végére 10\%-ra csökkentse. Magyarországon a végzettség nélküli iskolaelhagyók aránya elmarad az Európai Unió átlagától, 2011-ben és 2012-ben némileg nőtt az arány, de sikerült továbbra is az uniós átlag alatt tartani. Ennek a növekedésnek részben demográfiai (csökkenő tanuló népességen belül folyamatosan nő a $\mathrm{HH} / \mathrm{HHH}, \mathrm{SNI}$-s diákok aránya), részben oktatási okai vannak (lényegesen alacsonyabb arányban képes a köznevelés a hátrányos helyzetű tanulókat befejezett középfokú végzettségig eljuttatni, elsődlegesen a szakképzésben jelentkező magas végzettség nélküli iskolaelhagyás miatt). .i Oktatási rendszerünk az elmúlt 20 évben nem volt képes meghatározó mértékben csökkenteni a hátrányos és halmozottan hátrányos helyzetü gyerekek családi környezetéből fakadó elmaradásait. Mivel a végzettség nélküli iskolaelhagyás és az elfogadhatatlanul alacsony iskolai tudásszint között nagyon erős kapcsolat áll fent, a 2012-es PISA-mérések adatai alapján csökkenteni kell a végzettség nélküli iskolaelhagyás tekintetében veszélyeztetett tanulók számát." iii

„A végzettség nélküli iskolaelhagyás csökkentése közvetlenül javítja az egyének életesélyeit, foglalkoztathatóságukat, alkalmazkodóképességüket, a vonatkozó stratégia pedig közvetve járul hozzá a társadalmi szolidaritás, felzárkózás további erősítéséhez, a polarizálódás, a leszakadás és a szegénység elleni küzdelemhez."
„A végzettség nélküli iskolaelhagyás elleni küzdelem kizárólag szektorközi együttműködésben lehet sikeres, ezért szükségszerű egy, a hatékony szektorközi együttmúködést középpontba állító, a probléma megoldására irányuló, szektorokon átívelő, átfogó stratégia megalkotása."

„A végzettség nélküli iskolaelhagyás szektorközi megközelítése úgy értelmezhető, hogy a kormányzás és együttmúködés, az adatgyűjtésen és monitoringon alapul. Ennek három pillére: a prevenció, intervenció és kompenzáció."

„A végzettség nélküli iskolaelhagyás elleni stratégia célrendszere a rendszer-, az intézményi és az egyéni szintû tényezők számbavételén alapulva kívánja a végzettség nélküli iskolaelhagyást megakadályozni."

\section{HOGYAN LEHET A FENTI JAVASLATOKAT AZ IS- KOLA, MINT INTÉZMÉNY SZEMPONTJÁBÓL ÉR- TELMEZNI?}

Az iskolai oktatásra vonatkozó szakpolitikával foglalkozó munkacsoport (2014-2015) szakpolitikai üzeneteket fogalmazott meg, azonosítva annak alapfeltételeit, hogyan lehet úgynevezett iskolaszintű megközelítést alkalmazni a korai iskolaelhagyás visszaszorítása érdekében. ${ }^{4} \mathrm{~A}$ korai iskolaelhagyást célzó „átfogó iskolai megközelítés” legfontosabb feltételeit az ajánlások szerzői öt, szorosan összekapcsolódó tematikus területre osztották. Minden egyes területet alaposabban is kidolgoznak az „Eszköztár iskolák számára” platformon, gyakorlati példákkal, illetve intézkedésekkel is kiegészítve. ${ }^{5}$ Területek: 1. Iskolavezetés, 2. Tanulók támogatása, 3. Tanárok, 4. Szülók és családok, 5. Érdekelt felek bevonása.

\section{A STRATÉGIA, EGÉSZSÉGFEJLESZTÉSI SZEM- PONTÚ ÜZENETE}

Az érettségivel és magasabb végzettséggel rendelkezők várható élettartama Magyarországon nem

\footnotetext{
i $\mathrm{HH}=$ hátrányos helyzet, $\mathrm{HHH}=$ halmozottan hátrányos helyzet, $\mathrm{SNI}=$ sajátos nevelési igény

iii A PISA (Programme for International Student Assessment) vizsgálat célja annak felmérése, hogy a közoktatás kereteit hamarosan elhagyó 15 éves tanulók milyen mértékben rendelkeznek azokkal az alapvető ismeretekkel, amelyek a mindennapi életben való boldoguláshoz, a továbbtanuláshoz vagy a munkába álláshoz szükségesek.
} 
tér el a fejlett európai országok lakosainak várható élettartalmától. Egy populáció iskolai végzettsége és az egészsége szoros összefüggésben van. Populációs szinten, a korai iskolaelhagyás csökkentése jótékonyan hat a végzettségek fokának növekedésére és így az egészségi állapot javulására is.

A stratégia szemléletmódja tanulságos: a prevenciót már az óvodás korban meg kell kezdeni, ehhez kell társítani az egyének szintjén az optimális szociális támogatást és a „második esély” típusú kom- penzáló beavatkozásokat. A szektorközi megközelítés előfeltétel, több szakmának kell szorosan együttműködnie és a szolgáltatásokat elérhetővé tennie a rászorulók és veszélyeztetettek számára. $A z$ egészségfejlesztésben is lényegi szemlélet, a szektorközi-, szakmaközi megközelítés. Ehhez közös célok kijelölése szükséges. Ilyen távlati cél az egészség, jól-lét. A specifikus célokhoz ad újabb támpontokat a „Végzettség nélküli iskolaelhagyás elleni középtávú stratégia".

\footnotetext{
${ }^{1}$ Magyar Közlöny 2014. évi 150. szám.

${ }^{2}$ http://www.kormany.hu/download/5/fe/20000/V\%C3\%A9gzetts\%C3\%A9g\%20n\%C3\%A9lk\%C3\%BCli\%20iskolaelhagy\%C3\%A1s\%20.pdf (Elérve: 2016.11.09.)

${ }^{3}$ http://eur-lex.europa.eu/LexUriServ/LexUriServ.do?uri=OJ:C:2011:191:0001:0006:HU:PDF (Elérve: 2016.11.09.)

${ }^{4}$ http://ec.europa.eu/dgs/education culture/repository/education/policy/strategic-framework/expert-groups/documents/early-leaving-policy hu.pdf (Elérve: 2016.11 09.)

${ }^{5}$ http://www.schooleducationgateway.eu/hu/pub/resources/toolkitsforschools.htm (Elérve: 2016.11.09.)
} 